\title{
Spread Bancário e Enforcement Contratual: Hipótese de Causalidade Reversa e Evidência Empírica
}

\author{
Bruno Meyerhof Salama ${ }^{*}, \dagger$
}

\author{
Sumário: 1. Delineamento da Hipótese; 2. Revisão da Literatura; 3. Levantamento Empírico; \\ 4. Implicações Normativas; 5. Lições para o Economista; 6. Conclusão. \\ Palavras-chave: Spread Bancário, Viés Judicial, Direito e Economia. \\ Códigos JEL: K12, D86.
}

O consenso da literatura é o de que o baixo nível de enforcement dos contratos e garantias seja uma causa importante do alto spread bancário no Brasil. No entanto, por conta de uma dinâmica de causalidade reversa, pode haver uma endogeneidade na estimação deste efeito causal. 0 presente trabalho formula esta hipótese, apresenta evidência empírica preliminar e retira implicações normativas. Ao final, apresenta lições úteis para a análise econômica do direito e do Poder Judiciário.

The consensus in the literature is that the low level of enforcement of contracts and guarantees is an important cause of Brazil's high banking spreads. There may however be an endogeneity problem in the estimation of this causal effect due to reverse causality. This paper formulates this hypothesis, presents preliminary empirical evidence and draws normative implications. At the end, it presents useful lessons for economic analysis of law and of the Judiciary Power.

\section{DELINEAMENTO DA HIPÓTESE}

Uma extensa literatura documenta a proposição de que uma parcela entre aproximadamente 1/4 e 1/3 do alto spread bancário no Brasil corresponda ao custo de inadimplência na oferta do crédito. 0 problema do alto custo da inadimplência tem sido atribuído principalmente à baixa efetividade dos mecanismos judiciais para a exigibilidade do crédito bancário, que eleva o prêmio de risco embutido na taxa de juros cobrada do tomador. Essa dificuldade na exigibilidade do crédito é frequentemente referida

\footnotetext{
*Escola de Direito de São Paulo da Fundação Getulio Vargas (FGV Direito SP). Rua Rocha, 233, Bela Vista, São Paulo, SP, Brasil. CEP 01330-000. Email: bruno.salama@fgv.br

${ }^{\dagger}$ Agradeço aos comentários de Klênio Barbosa, Bernardo Guimarães, Paulo Furquim. Agradeço a Danilo Carlotti pelo auxílio na realização do levantamento empírico. Um agradecimento especial a Thomas Junqueira, Ricardo Cabral e ao pessoal da Digesto Pesquisa e Banco de Dados pela generosidade de fornecer-me dados sobre litígios no Brasil. Agradeço a Bruno Becker e Anna Binotto pelo auxílio no levantamento de bibliografia.
} 
sob a rubrica do baixo nível de enforcement, termo usual na literatura internacional em economia dos contratos. Praticamente todos os estudiosos do mercado de crédito brasileiro concordam, então, que o baixo nível de enforcement dos contratos e garantias é uma causa importante do alto spread bancário no Brasil.

O presente trabalho apresenta uma hipótese de causalidade reversa, a saber, a de que 0 alto spread seja causador do baixo enforcement. A proposição é a de que haja duas dinâmicas na relação entre enforcement e spread bancário que se retroalimentam. De um lado, o baixo nível de enforcement causa aumento do spread. Mas de outro, em um feedback loop, o alto spread também induz o baixo nível de enforcement. ${ }^{1}$ A primeira relação causal vem sendo minudentemente debatida na literatura; a segunda, até onde pude pesquisar, nunca foi formulada. ${ }^{2}$ Dela me ocupo neste trabalho.

A intuição básica da hipótese de causalidade reversa aqui formulada é a de que os juízes se sentem cada vez menos confortáveis em dar o enforcement conforme a taxa de juros do contrato se eleva. Por exemplo, o juiz está mais propenso a mandar pagar rigorosamente o que está previsto em contrato quando a taxa de juros estipulada é de $12 \%$ ao ano do que quando é de $12 \%$ ao mês. Em outras palavras, a hipótese de causalidade reversa é a de que, quando se discute em juízo a validade de um contrato de financiamento, os integrantes do Poder Judiciário têm maior propensão a julgar favoravelmente aos devedores conforme aumenta a taxa de juros do contrato.

Implícita nesta construção está uma hipótese sobre as preferências dos juízes. Trata-se especificamente de um gosto (taste) por juros contratuais mais baixos, em oposição a juros mais altos. Não se trata, portanto, de uma preferência por um tipo de parte do contrato (devedores ou credores; fortes ou fracos; gregos ou troianos), mas de uma preferência por uma característica do próprio contrato.

Ao formularmos a conjectura de que o Judiciário tenha sistematicamente uma preferência por contratos com juros menores, somos levados, também, a refletir sobre os motivos para tanto. Há duas formas de enxergarmos o problema.

A primeira é tratar a decisão dos juízes sobre a validade/invalidade da taxa de juros contratual como um teste de hipóteses clássico. ${ }^{3}$ A hipótese nula é "a taxa de juros do contrato deve ser seguida" e a hipótese alternativa é "a taxa de juros do contrato deve ser reduzida". 0 juiz pondera sobre a legalidade da taxa de juros do contrato à luz de cânones jurídicos estabelecidos como a razoabilidade, a abusividade, a função social e a equidade. O juiz "monta", assim, uma estatística apropriada e estabelece um intervalo de confiança para determinar a região de rejeição. Quanto mais elevadas as taxas de juros, maior a probabilidade de caírem na zona de rejeição.

Uma variante desse teste de hipóteses é o juiz ponderar sobre a razoabilidade da legislação aplicável, em vez de ponderar sobre a razoabilidade da taxa de juros do contrato. Um teste de hipóteses sobre a razoabilidade da legislação faz sentido especialmente quando se considera que a tolerância à taxa de juros não depende apenas da previsão contratual e da deliberação do juiz, mas depende também da existência, ou não, de uma regra legislada que imponha tetos à taxa de juros do contrato.

Considere, por exemplo, que na Constituição de 1988 havia uma proibição expressa à estipulação de juros "reais" acima de $12 \%$ ao ano. O Supremo Tribunal Federal (STF) julgou tal regra como não autoaplicável — isto é, na prática, desconsiderou a regra —, e podemos supor que tenha agido assim por uma consideração de prudência. No teste de hipóteses, a hipótese nula teria sido "a regra dos $12 \%$ deve ser considerada aplicável" e a hipótese alternativa teria sido "a regra dos $12 \%$ deve ser considerada

\footnotetext{
${ }^{1}$ Uma variação dessa hipótese pode ser articulada assim: a elevação da taxa de juros reduz a propensão do Poder Judiciário a dar o enforcement do contrato. Um corolário dessa hipótese é o de que, ceteris paribus, uma elevação do spread reduziria o nível de enforcement contratual. Nesse caso, a causalidade reversa não decorreria da hipótese central, mas de seu corolário. Para os presentes fins, tanto a hipótese original quanto esta variação encaminham as mesmas implicações e conclusões.

${ }^{2}$ Exceto de maneira indireta em Salama (2012).

${ }^{3}$ Seria ainda possível modelar a decisão como um teste de hipóteses bayesiano, em que os juízes aprendem com decisões anteriores. Para os presentes fins, o resultado seria praticamente o mesmo.
} 
como não auto-aplicável". Em um ambiente de juros altos e inflação alta, a chance de um teto como esse (de $12 \%$ ao ano) ser minimamente exequível e razoável é muito pequena. Assim, mesmo com um intervalo de confiança bastante grande, a hipótese nula teria mesmo que ter sido rejeitada.

Repare em uma diferença importante entre esses dois testes de hipóteses. O teste sobre a razoabilidade da taxa de juros do contrato serve apenas para decidir se a taxa é excessivamente alta; há, portanto, apenas uma zona de rejeição. Já o teste de hipóteses para deliberar sobre a legislação permite deliberar tanto sobre se a lei é excessivamente estrita quanto sobre se a lei é excessivamente leniente. Há, portanto, duas zonas de rejeição da hipótese nula.

O exemplo do teto de $12 \%$ acima mencionado ilustra a zona de rejeição em que se pondera sobre se a lei é muito estrita (ou seja, se o teto é muito baixo). Mas se considerarmos a regra atualmente prevista na Lei 4595/64, que, de modo geral, acabou por abolir os tetos aos juros em contratos de financiamento, ${ }^{4}$ podemos olhar o problema da seguinte forma: quando um juiz brasileiro decide invalidar um contrato por julgar sua taxa de juros excessivamente alta ele está, na verdade, rejeitando a hipótese nula "a legislação deve ser aplicada" para casos com juros muito altos (e a hipótese alternativa, naturalmente, é "a legislação não deve ser aplicada"). O teste de hipóteses sobre a legislação é, portanto, mais geral que o teste sobre a taxa de juros do contrato. ${ }^{5}$

Alternativamente à concepção da decisão dos juízes como decorrendo de um teste de hipóteses, pode-se simplesmente especular sobre os motivos que levam juízes a validar ou invalidar a taxa de juros de um contrato sub judice. Neste segundo caso, pode-se pensar em um contínuo em que os juízes cada vez mais discordam da taxa de juros do contrato (ou da própria autorização legislativa para contratos com juros altos). A decisão resulta de uma ponderação entre a regra contratual (ou a regra legislada) e o juízo que o juiz faz a respeito dessa regra. 0 peso dado à regra contratual (ou legislada) depende do grau de discordância do juiz ante tal regra.

A origem da discordância do juiz ante a regra contratual ou legislada é, no entanto, uma questão de foro íntimo. Ela é exógena à formulação econômica. É uma questão para os psicólogos, mas pode-se cogitar sobre muitas possibilidades. Ao invalidarem contratos com juros muito elevados, talvez os juízes ainda estejam presos ao preconceito medieval contra a cobrança de juros — até porque a Bíblia pode bem ter sido reinterpretada, mas não foi rescrita, e lá ainda há 31 passagens sugerindo a vedação à cobrança de juros. ${ }^{6}$ Mas a verdade é que a Bíblia não é, e provavelmente nunca foi, interpretada apenas literalmente; o Decreto de Graciano do século XII já continha caminhos interpretativos para a cobrança de juros, e a escolástica tardia abriu ainda mais outros; e, de mais a mais, não me parece nem um pouco óbvio que os juízes brasileiros simplesmente odeiem a cobrança de juros ou os bancos.

Logo, seria possível fazer muitas outras hipóteses para essa investigação psicológica. Ao intervir em contratos, quem sabe os juízes queiram apenas corrigir falhas (reais ou imaginadas) no processo político de feitura da legislação, de regulação do sistema financeiro ou da própria contratação privada. Ou talvez os juízes entendam que, de alguma forma, ao vedarem juros muito altos estejam no fundo protegendo o bom funcionamento e eficiência dos mercados de crédito.

Na verdade, o espaço para especulação só encontra limite na capacidade de imaginar. Pode ser que os juízes estejam motivados por intuições de justiça distributiva e queiram no fundo proteger o consumidor, que enxergam como em geral mais vulnerável (até mesmo porque juízes são eles próprios consumidores de muitos produtos, inclusive bancários). Ou então, pode ser que os juízes sigam outras orientações políticas ou ideológicas pouco simpáticas à cobrança de juros. Não é possível saber ao certo,

\footnotetext{
${ }^{4} \mathrm{O}$ art. $4^{\circ}$, IX, da Lei 4595/64, dispôs ser da competência do Conselho Monetário Nacional limitar as taxas de juros nas operações financeiras "sempre que necessário". o CMN, de modo geral, não impôs tais limitações.

${ }^{5}$ Em Guimarães \& Salama (2017), a hipótese de causalidade reversa aqui delineada é formulada como parte de um modelo geral sobre a propensão dos juízes a seguirem proibições legislativas, inclusive vedações à cobrança de juros elevados. Recorre-se, então, ao teste de hipóteses sobre a razoabilidade da legislação.

${ }^{6}$ Cf. https: //www . openbible. info/topics/usury (acesso em 15/11/2016).
} 
e, por isso, sobre a origem psicológica da aventada preferência por juros mais baixos não faço, nem preciso fazer, nenhuma hipótese.

Prossigo da seguinte forma. A seção 2 revisa a literatura. A seção 3 apresenta o levantamento empírico realizado, identificando uma correlação entre vitórias judiciais de devedores e aumento da taxa de juros em financiamentos de automóveis no estado de São Paulo. A seção 4 retira implicações normativas para os estudos sobre spreads bancários, para a microeconomia teórica, para o debate sobre a imposição de tetos aos juros remuneratórios, para as políticas públicas voltadas à redução do spread e para o debate público sobre o spread bancário. A seção 5 traz lições que se pode depreender ou que estão associadas à hipótese aqui formulada e que esclarecem o papel do Poder Judiciário no esquema público de enforcement contratual. A seção 6 conclui.

\section{REVISÃO DA LITERATURA}

\subsection{0 problema dos spreads bancários no Brasil}

Os spreads bancários são altos em toda a América Latina (Gelos, 2006), mas o problema parece ser particularmente agudo no Brasil (Banco Mundial, 2006). Os dados mais recentes disponibilizados pelo Banco Mundial, definindo spreads como taxa de empréstimo menos taxa de remuneração do depositante (lending rate minus deposit rate, \%), colocam o Brasil na nada honrosa posição de terceiro país com maiores taxas de intermediação do mundo, atrás apenas de Madagascar e Maláui (Banco Mundial, 2015). 0 problema não é novo, e os dados mostram que o Brasil é um outlier na comparação internacional desde pelo menos a década de 90 (Aronovich, 1994; Afanasieff, Lhacer \& Nakane, 2002).

A gravidade do problema ensejou o surgimento de uma extensa literatura buscando identificar suas causas. Paula \& Oreiro (2007), Ono, Oreiro, Paula \& Silva (2004), Oliveira \& Carvalho (2007) e Manhiça \& Jorge (2012) encontram evidência de que a política monetária rígida adotada no Brasil cause elevação dos spreads bancários. Os canais de transmissão seriam o aumento da incerteza quanto à necessidade de refinanciamento pelos bancos, o potencial aumento nos níveis de inadimplência, o aumento na volatilidade das taxas de juros, o aumento de aversão ao risco pelos bancos e a existência de uma relação de longo prazo entre o risco de taxa de juros e o risco de crédito.

A maior parte da pesquisa sobre os spreads bancários, no entanto, tem se dedicado a identificar e mensurar suas causas microeconômicas e institucionais. Um dos aspectos estudados é o das margens dos bancos, que têm sido relativamente elevadas, e o nível de competição no mercado bancário brasileiro (Belaisch, 2003; FMI, 2012). Lucinda (2010) não encontrou evidência de colusão perfeita, L. S. Alencar (2011) encontrou evidência de que a consolidação no setor bancário impactou o nível de spreads e Nakane \& Rocha (2010) concluíram haver razoável nível de competição no mercado bancário brasileiro. Barbosa, Rocha \& Salazar (2015) e Barbosa, Cardoso \& Azevedo (2016), no entanto, alertaram para a existência de viés de superestimação da intensidade de concorrência bancária. L. Alencar, Andrade \& Barbosa (2017) concluíram que a falta de competição no mercado bancário diminui o potencial de redução de spread bancário que é propiciado por reformas que melhoram os níveis de enforcement contratual.

Estudo do Banco Central do Brasil (BCB) de 1999 buscou identificar os componentes dos spreads bancários no período entre maio e julho de 1999, e concluiu que $35 \%$ do spread era resultado da inadimplência. $O$ restante seria atribuível ao mark-up entre custo de captação e custo de aplicação: despesas administrativas (22\%), IR/CSLL (11\%), impostos indiretos (14\%) e lucro líquido (18\%). Nos anos seguintes, o BCB foi refinando a análise da composição do spread, separando, inclusive, empréstimos a pessoas fisicas e jurídicas, e analisando diferentes tipos de produtos financeiros (BCB, 1999, 2000, 2001, 2002, 2003, 2004a).

Os dados foram mudando conforme a metodologia ia se sofisticando. O relatório do BCB de 2004 já indicava o custo administrativo como o fator mais relevante $(26,37 \%)$, seguido da "cunha tributária" $(20,81 \%)$, inadimplência $(19,98 \%)$, custo do compulsório $(5,04 \%)$ e custo do FGC $(0,24 \%)$. Havia também 
uma variável de "resíduo" (27,56\%), uma parcela não resolvida na composição do spread que decorreria da existência de subsídios cruzados em operações de crédito direcionado. Em 2008, a metodologia de cálculo passou a isolar a parcela referente aos subsídios cruzados decorrentes da concessão de crédito direcionado, e introduziu outros aperfeiçoamentos na mensuração dos efeitos dos recolhimentos compulsórios e dos impostos indiretos sobre o spread (Koyama et al., 2008).

O mais recente relatório disponibilizado pelo BCB (2014) é ainda mais pormenorizado na decomposição do spread, traçando também distinções entre crédito direcionado e livre, clientes preferenciais e demais clientes e bancos privados e públicos. A tabela que compara a evolução do spread decomposto no período entre 2007 e 2014 mostra a margem líquida dos bancos oscilando em torno de $35 \%$ do spread, e o custo de inadimplência se estabilizando em torno de $25 \%$ do spread (p.42). A divulgação desses números pelo $\mathrm{BCB}$ e o eterno dilema dos juros altos no Brasil foram com o tempo impulsionando o surgimento de um conjunto de estudos focados em analisar as causas da alta inadimplência na composição das taxas de spread.

\subsection{A "ineficiência judicial": instituições formais e informais}

É justamente na discussão das causas do custo de inadimplência na composição das taxas de spread que o debate econômico encontra a discussão sobre as instituições jurídicas e judiciais brasileiras. Iniciando com Pinheiro (1996), e logo adiante com Aith (1998), Pinheiro \& Cabral (1998), Laeven (2003), a literatura passou a enxergar na "ineficiência judicial" - morosidade, custos, parcialidade e imprevisibilidade - um fator limitante à redução do spread para padrões internacionais, à expansão do crédito e ao crescimento econômico. A hipótese é intuitiva: quanto menor a probabilidade de enforcement do pacto contratual, maior o prêmio de risco para compensar o custo esperado da inadimplência.

Essa hipótese foi testada e confirmada por diversos levantamentos empíricos (BCB, 2004b, 2005). Há hoje boa evidência de que a melhoria de alguns mecanismos de execução de garantias tenha causado significativa redução nas taxas de juros de certas modalidades de financiamentos e que tenha permitido a expansão do crédito. Exemplos já clássicos incluem a criação do crédito consignado (em que pensões e outros pagamentos pelo Estado para os tomadores são automaticamente debitados em favor do banco financiador em caso de inadimplemento do tomador) e da alienação fiduciária de imóvel (que agilizou a retomada e venda de habitações financiadas).

Há, ainda, alguma evidência preliminar de que a edição de uma nova legislação falimentar em 2005 tenha causado ampliação no crédito de longo-prazo para as empresas (Araujo, Ferreira \& Funchal, 2012; Ponticelli \& Alencar, 2013), se bem que o estudo mais recente (Barbosa et al., 2016) tenha concluído que a nova legislação falimentar não foi eficaz no sentido de diminuir as taxas de inadimplência das pessoas jurídicas nem o spread bancário. Apesar disso, o senso comum dessa literatura sobre instituições jurídicas e crédito segue sendo o de que, quando o enforcement melhora, a tendência é para a queda dos juros e para o aumento da oferta de crédito.

$\mathrm{O}$ reconhecimento pela literatura de que a ineficiência judicial estaria a impulsionar o aumento dos níveis de spread conduziu a pesquisa, então, à discussão das suas causas. Aqui, a literatura parece enveredar por dois caminhos distintos. 0 primeiro associa a ineficiência judicial aos mecanismos burocráticos e procedimentais que tornam o processo lento, a execução de garantias difícil, inclusive durante a falência, e a circulação de informação entre agentes truncada. Com North (1991), podemos chamar esses de mecanismos formais, porque sua mudança depende da edição de leis e da implantação de reformas burocráticas.

A busca pelo aprimoramento desses mecanismos formais - a implantação do que às vezes se chama de infraestrutura jurídica ${ }^{7}$ - tem sido uma preocupação constante do governo brasileiro. Relatório do BCB (2004a) detalhou as medidas tomadas, que incluíram a criação de diversos mecanismos legais

\footnotetext{
${ }^{7}$ Para uma proveitosa crítica a essa ideia, ver Milhaupt \& Pistor (2008).
} 
voltados a acelerar a circulação de informações sobre prestadores e tomadores e, especialmente, de mecanismos voltados a apressar e assegurar a execução de garantias. Daí a criação da Cédula de Crédito Bancário, da alienação fiduciária de bens imóveis, do crédito consignado, a reforma da Lei de Falências e a reforma do Código de Processo Civil, dentre diversas outras iniciativas.

Há ainda uma segunda causa a que parcela da literatura econômica atribui o problema da ineficiência judicial. Trata-se, ainda com North (1991), de instituições informais, isto é, das restrições ligadas a modelos mentais como tabus, costumes, tradições e códigos de conduta. Em particular, trata-se aqui do sistema de crenças dos membros do Poder Judiciário. O diagnóstico se prende, então, não aos incentivos que exsurgem das regras previstas em alguma lei específica, mas das mentalidades das pessoas, particularmente dos integrantes do Poder Judiciário.

\subsection{A hipótese do viés anti-credor}

A manifestação mais influente na literatura econômica dessa descrição da crença dos julgadores que impulsionaria o aumento dos spreads pode ser localizada na hipótese da existência de um "viés anticredor". Tal hipótese sugere que o Poder Judiciário brasileiro tenha preferência por proteger devedores e que, ao fazê-lo, acabe gerando o aumento de spread como um efeito de segunda ordem.

O primeiro a defender esta hipótese no contexto da discussão dos spreads bancários parece ter sido Pinheiro (1996, 1998). A ideia é bem resumida em trabalho de 2003 (Pinheiro, 2003, p.29-30), nos seguintes termos:

A não-neutralidade do magistrado significa que ele se alinha claramente com os segmentos sociais menos privilegiados da população: entre o inquilino e o senhorio, ele se inclina a favor do primeiro; entre o banco e o devedor, ele tende a ficar com o último, e assim por diante. Isso faz com que, nos casos em que essa não-neutralidade é clara e sistemática, os segmentos menos privilegiados sejam particularmente penalizados com prêmios de risco (isto é, preços) mais altos. [...] 0 banco cobrará um spread mais alto pelo maior risco de inadimplência, o investidor exigirá um retorno mais alto para compensar o risco de expropriação, o empregador exigirá pagar um salário mais baixo para cobrir o risco de ser acionado na Justiça do Trabalho. E, por essa lógica, como os agentes se adaptam, quanto menos privilegiado for o grupo social, e maior o "risco" de receber proteção, maior tenderá a ser a discriminação. [...] Isso significa que são exatamente as partes que o magistrado buscava proteger que se tornam as mais prejudicadas por essa não-neutralidade. (grifo meu)

Diversos trabalhos baseados em questionários parecem ter sido importantes para motivar a hipótese de viés anti-credor acima formulada. Em um questionário organizado por Sadek (1995), aproximadamente $1 / 3$ dos entrevistados indicava preferir o compromisso com a "justiça social" à estrita aplicação da lei. Em dois estudos do Idesp (mencionados em Pinheiro, 1998) a respeito da performance do Judiciário em diferentes estados, os respondentes indicaram ser a "parcialidade" um dos graves problemas do sistema judicial brasileiro.

Também bastante citada é uma pesquisa de Vianna, Carvalho, Melo \& Burgos (1996), em que 83\% dos 3.927 magistrados entrevistados concordaram com a assertiva de que "o Poder Judiciário não é neutro, e que em suas decisões o magistrado deve interpretar a lei no sentido de aproximá-las dos processos sociais substantivos e, assim, influir na mudança social." No mesmo estudo, $26 \%$ dos entrevistados se identificavam fortemente com a proposição de que "a magistratura que, por definição, não está comprometida com a representação de interesses deve exercer um papel ativo no sentido de reduzir as desigualdades entre regiões, indivíduos e grupos sociais."

Há ainda um estudo conduzido por Lamounier \& De Sousa (2002) concluindo que os membros do Poder Judiciário dão menos valor ao cumprimento dos contratos do que outros grupos integrantes da 
"elite" brasileira. Em outro estudo referido em Pinheiro (2003, p.25), foi perguntado se os juízes, levados a optar entre duas posições extremas, escolheriam entre (i) respeitar sempre os contratos, independentemente de suas repercussões sociais, ou (ii) tomar decisões que violem contratos na busca da justiça social, sendo que $73,1 \%$ optaram pela alternativa (i).

Para a motivação da hipótese do viés anti-credor são comuns também referências a entrevistas com advogados e a observação de que o mercado de crédito seria particularmente sensível à qualidade do Poder Judiciário (e.g. Pinheiro \& Cabral, 2001). Todo esse conjunto de levantamentos contribuiriam para a proposição da "não-neutralidade do magistrado, que dá origem a decisões viesadas ou com pouca previsibilidade [...] [um problema econômico] tão importante quanto a morosidade [do Judiciário]" (Pinheiro, 2003).

A hipótese do viés anti-credor foi com o tempo ganhando força na literatura econômica. O próprio $\mathrm{BCB}$ (2004a, p.43), no seu balanço sobre o conjunto de atividades voltadas à redução do spread no começo da década de 2000 , falava da importância das iniciativas de "conscientização de juízes", tudo para "realizar um esforço [...] para mostrar que as decisões que beneficiam um tomador de empréstimo específico têm repercussões amplas, que podem prejudicar os tomadores de empréstimos como um todo."

\subsection{A hipótese da incerteza jurisdicional}

Uma das mais influentes formulações utilizando a hipótese do viés anti-credor coube a Arida, Bacha \& Resende (2005). Para esses autores, a "incerteza jurisdicional" seria, ao lado da inconversibilidade da moeda brasileira, a principal razão para o não florescimento do mercado de crédito de longo prazo no Brasil. A lógica do argumento foi a de que, para explicar a persistência do alto custo do capital no Brasil, teria que haver alguma distorção de natureza permanente, porque as hipóteses até então existentes na literatura ${ }^{8}$ - equilíbrio macroeconômico sub-ótimo, insuficiência de ajuste fiscal ou sequência de choques negativos - não explicavam adequadamente a persistência do alto custo do dinheiro no país.

Em particular, a rigidez da política monetária brasileira seria compreensível sob o regime de câmbio fixo que prevalecera até 1999, mas sua permanência após a flutuação do câmbio continuaria ainda sem explicação. A conjectura dos autores foi, assim, a de que distorção seria e enorme dificuldade para o enforcement de contratos. Confira-se:

It is an uncertainty of a diffuse character that permeates the decisions of the executive, legislative, and judiciary and manifests itself predominantly as an anti-saver and anti-creditor bias. The bias is not against the act of saving but against the financial deployment of savings, the attempt to an intertemporal transfer of resources through financial instruments that are, in the last analysis, credit instruments. (Arida et al., 2005, p.270, grifo meu)

Como justificativa para essa conjectura, Arida et al. indicaram a existência de um mercado de títulos de longo prazo para devedores brasileiros apenas no exterior, mas não dentro do Brasil. Tal risco seria materializado pela edição de leis que dificultavam a exigibilidade de créditos e, ademais, pela frequente ocorrência de "atos do príncipe" - ações de governo que reduzem unilateralmente o valor de contratos, como revisões e calotes - e, ainda, pela dificuldade de dar cumprimento perante o Poder Judiciário desses mesmos contratos. Dito de forma simples, isso quer dizer que o Poder Judiciário atuaria sistematicamente de maneira contrária aos credores não apenas por conta dos seus mecanismos formais, mas também por conta do viés de seus integrantes.

Nessa linha, a mudança do viés poderia ser traçada, ainda, ao próprio padrão interpretativo do direito que se gestava no Poder Judiciário a partir da edição da Constituição de 1988 — um argumento, aliás, já levantado anteriormente em Pinheiro \& Cabral (2001, p.17). Confira-se:

\footnotetext{
${ }^{8}$ Com o tempo, diversas outras formulações foram apresentadas para explicar a persistência da política monetária rígida no Brasil. Uma boa revisão dessa literatura pode ser encontrada em Barboza (2015).
} 
Jurisdictional uncertainty worsened after the 1988 Constitution introduced the possibility of changes in the interpretative emphasis between conflicting constitutional principles, particularly the subordination of private property to its social function. The Constitution of 1988 is a striking example of how the paternalistic attempt to substitute the government for the market in the allocation of long-term resources aggravates jurisdictional uncertainty. (Arida et al., 2005, p.272)

O grande indício da existência de um problema de incerteza jurisdicional particularmente grande no Brasil estaria, então, na existência de mercado de títulos de longo prazo para devedores brasileiros apenas fora, mas não dentro, do Brasil. De resto, a fundamentação de Arida et al. pouco diferiu do que já se vinha mencionando em trabalhos anteriores. Assim, o texto formulador da hipótese de incerteza jurisdicional referiu novamente o questionário de Lamounier \& De Sousa (2002) e mencionou um estudo de Amadeo \& Camargo (1996) que retratara a parcialidade da Justiça do Trabalho — cuja versão inicial, aliás, já houvera sido mencionada no trabalho seminal de Pinheiro \& Cabral (1998). Também não faltaram evidências anedóticas, como segue:

The bias is transparent in the negative social connotation of figures associated to the moneylender - "financial capital" by opposition to "productive capital", "banker" as opposed to "entrepreneur". The debtor is viewed on a socially positive form, as an entity that generates jobs and wealth or appeals to the bank to cope with adverse life conditions. This bias may be observed more or less everywhere, but it is particularly acute in Brazil, probably because of the deep social differences and the high levels of income concentration in the country. Cultural and historical factors could also have facilitated the dissemination of this anti-creditor bias. (Arida et al., 2005, p.271)

\subsection{Viés e empiria}

Yeung \& Azevedo (2015) procuraram testar de forma rigorosa a hipótese de favorecimento sistemático do Judiciário aos devedores nas relações contratuais. O trabalho partiu de uma base de 1.687 decisões do Superior Tribunal de Justiça (STJ) entre os anos de 1998 e 2008. Foram extraídas variáveis sobre o tipo de recorrido ou recorrente, ou seja, se a parte era pessoa jurídica, pessoa física ou instituição financeira e tipo de dívida. Os resultados mostraram que não há viés explícito pró-devedor (que poderia ser identificado apenas nas estatísticas descritivas).

Em novo teste, Yeung, Carvalho \& Silva (2012) concluíram pela inexistência de viés pro-devedor no STJ. Esses resultados são consistentes com trabalhos anteriores de Ferrão \& Ribeiro (2007) e Ribeiro (2007), em que se testava a manutenção em juízo de cláusulas contratuais tidas por pro-devedor, e se concluía pela existência de viés pro-devedor (e não pro-credor). A tônica desses estudos, no entanto, foi testar a existência de viés pro-credor a partir das decisões judiciais da seguinte maneira: mais decisões pro-credor do que devedor sugeririam viés pro-credor, e vice-versa. Pode haver, entretanto, um viés de seleção nessa metodologia.

É que nas disputas contratuais existem dois grupos, o das disputas que são decididas judicialmente e o das disputas em que se chega a um acordo. Priest \& Klein (1984) mostraram, no entanto, que há uma diferença sistemática entre o grupo das disputas judicializadas e o grupo das disputas não judicializadas. O motivo é que, antes de entrarem em juízo, as partes consideram as chances de vencer a disputa. Por isso, haveria uma tendência para que as decisões judiciais convergissem para um padrão de 50-50 na solução de temas controversos.

Voltando ao caso brasileiro, isso quer dizer o seguinte. Como empresas, indivíduos e bancos têm custos diferentes para acessar o STJ, as decisões analisadas por Yeung et al. (2012) e Yeung \& Azevedo (2015) podem não ser amostras representativas de cada um desses grupos. Por exemplo, se os credores 
antecipam perder, deixam de entrar em juízo, o que faz com que o grupo de devedores passe, em média, a vencer menos ações. Em equilíbrio, a tendência é que os juízes decidam 50-50. As variações em torno desse patamar decorreriam, então, de assimetria de informação ou diferenças no custo de acesso. Assim, pode haver viés pro-devedor ou pro-credor mesmo se as decisões judiciais forem precisamente 50-50. Essa observação é consistente com alguns levantamentos empíricos realizados no Judiciário brasileiro (e.g. Nunes \& Trecenti, 2015).

Diante dessa dificuldade, Yeung \& Azevedo (2015) discutem em seu trabalho correlações condicionais. Vale citar:

As estimações das probabilidades condicionais indicam que o tipo de recorrente ou recorrido tem impactos sobre o resultado da decisão e também sobre a probabilidade da decisão estadual ser revertida pelo STJ. Em alguns casos, diferentemente do que argumentam ABL (2005) [Arida et al., 2005, supra], a decisão dos Ministros tende a favorecer o credor, principalmente nos casos de dívidas comerciais, quando instituições financeiras são as recorrentes, e quando firmas (pessoas jurídicas) são a parte recorrida. Este resultado merece especial atenção, uma vez que ABL (2005) imputam ao alegado viés pró-devedor a atrofia do mercado de crédito de longo prazo no Brasil. o que se nota, contudo, é que justamente nas dívidas comerciais - aquelas relacionadas a investimentos — a tendência do STJ é favorecer o credor, na comparação com os demais tipos de dívida. Não há, portanto, elementos nos dados para sustentar a proposição de que há um viés de decisão no judiciário cujo efeito seja prejudicar o mercado de crédito para investimentos. (p.17)

De qualquer forma, a ideia de um viés anti-credor por parte do Poder Judiciário segue sendo influente nos círculos de policy (e.g. Banco Mundial, 2006). Por outro lado, o viés segue sendo tratado basicamente como uma restrição exógena. Tal qual a origem dos sistemas jurídicos (Common Law vs. Civil Law, na literatura de law and finance popularizada por La Porta, Lopez-De-Silanes, Shleifer \& Vishny, 1998), supõe-se que o viés exista por fazer parte do sistema de crenças dos integrantes do Poder Judiciário, que é uma consideração não explicável economicamente. A hipótese de causalidade reversa aqui formulada pode, assim, ser enxergada como uma explicação alternativa à própria discussão de viés.

\section{LEVANTAMENTO EMPÍRICO}

Com o auxílio de text mining, foram examinadas decisões judiciais em que os devedores questionavam a validade das taxas de juros pactuadas em financiamentos de automóveis com alienação fiduciária. Os resultados indicam a existência de correlação entre aumento da taxa de juros e vitórias judiciais dos devedores, o que é consistente com a hipótese de causalidade reversa motivadora deste trabalho. Essa correlação sugere que o Poder Judiciário delibere sobre a substância da contratação e que, conforme a taxa de juros do contrato de financiamento cresça, torne-se mais propenso a julgar em favor dos devedores.

\subsection{Metodologia}

O text mining é um processo computacional de obtenção de informação de alta qualidade a partir de textos. Um software foi programado para ler milhares de decisões disponíveis online usando um algoritmo de classificação das sentenças a partir de uma variação da técnica Term Based Method. A linguagem de programação foi Python, sendo que a principal biblioteca utilizada para processamento dos dados foi a Natural Language Toolkit (NLTK).

Os textos foram classificados a partir da existência, ou não, de termos específicos das seções relevantes do universo de sentenças pesquisado. Procuramos, por exemplo, as sentenças em que aparecia a palavra "banco" na seção em que são descritos os réus. Ainda, para localizar as sentenças em que a taxa 
de juros era apresentada expressamente, foram selecionados somente as sentenças que continham os termos "juros" e o símbolo "\% ". A palavra "sentença" foi encontrada em alguns milhares de textos em determinado local do cabeçalho, identificado após o uso da técnica chamada de parsing of the texts. Ao fim do levantamento, realizamos diversos testes de conferência manual para checar a consistência do levantamento realizado pelo software.

Para organizar os dados referentes à taxa de juros do contrato, foram realizadas duas manipulações. Primeiro, todas as taxas de juros foram normalizadas para indicar sempre uma taxa mensal. Segundo, foi necessário consolidar em uma única taxa as situações em que as sentenças judiciais tratavam separadamente dois "tipos" de juros no contrato. É que a legislação e a jurisprudência reconhecem uma distinção entre os juros "remuneratórios" (cobrados a partir do momento da concessão do financiamento) e os juros "moratórios" (cobrados após a mora, isto é, o inadimplemento do devedor). Cada um desses "tipos" de juros costuma ser discutido judicialmente em separado. Não há aqui como resumir todo o debate sobre o tema, nem isso é necessário.

O importante é apontar que em contratos com consumidores, como aqueles objeto desta pesquisa, geralmente acontece o seguinte. Antes da mora, são cobrados juros remuneratórios. Após a mora, esses juros remuneratórios continuam a ser cobrados, mas a eles são acrescidos juros moratórios (geralmente limitados a $1 \%$ ao mês, com capitalização mensal ou diária). Assim, para consolidar tudo em uma única taxa, optamos por (i) no caso de disputa antes da mora, simplesmente indicar os juros remuneratórios; ou, (ii) no caso de disputa judicial após a mora, somar os juros remuneratórios e os juros moratórios (por exemplo, se o contrato previa uma taxa de juros de 3\% ao mês e cobrava-se uma taxa de juros moratórios de $2 \%$ ao mês, a taxa de juros do contrato foi indicada como sendo de $5 \%$ ao mês).

A pesquisa foi limitada às sentenças de primeiro grau proferidas no estado de São Paulo, que é o estado com maior quantidade de ações judiciais do país. A escolha de São Paulo também se justifica porque, ao contrário da maioria dos outros estados, desde 2014 todas as sentenças paulistas estão disponíveis online, o que facilitou o acesso aos dados. A classificação dos processos resultou em um pool de textos que foram, posteriormente, lidos para que as informações finais fossem extraídas manualmente.

A pesquisa original nos levou a 11.000 decisões. $^{9}$ Deste universo original, apenas mantivemos as decisões que preenchiam os seguintes critérios: (i) o devedor era o autor da ação; (ii) o banco era o réu; (iii) a taxa de juros do contrato era expressamente informada na sentença judicial; e (iv) o devedor estava especificamente questionando judicialmente a legalidade da taxa de juros do contrato (ou dos juros moratórios, ou dos juros remuneratórios, ou de ambos, como é mais comum).

\subsection{Resultados}

Foram encontradas 888 ações judicias que atendiam aos critérios da pesquisa. As ações foram então separadas em dois grupos: "rejeitadas" (em que o juiz mantinha a legalidade das taxas de juros pactuadas) e "aceitas" (em que o juiz reduzia a taxa de juros contratada). 862 ações foram rejeitadas e 26 foram aceitas. A taxa de juros média das ações rejeitadas foi de 1,936454\% ao mês (com 0,5155\% de desvio padrão). A taxa de juros média das ações aceitas foi de $11,66739 \%$ ao mês $(5,949813 \%$ de desvio padrão). Esses resultados estão ilustrados na Tabela 1 e na Figura 1.

\subsection{Discussão dos resultados}

Durante o período selecionado, a inflação foi de aproximadamente $0,5 \%$ ao mês e a taxa Selic esteve em aproximadamente $1 \%$ ao mês. Os resultados obtidos são, portanto, consistentes com a observação largamente documentada de que os spreads bancários são elevados no Brasil.

${ }^{9}$ Coincidentemente, um número redondo. 
Tabela 1. Taxa de juros do contrato e decisões judiciais.

\begin{tabular}{lccc}
\hline $\begin{array}{c}\text { Taxa de juros } \\
\text { mensal }\end{array}$ & $\begin{array}{c}\text { Aceitas } \\
\text { (pró-devedor) }\end{array}$ & $\begin{array}{c}\text { Rejeitadas } \\
\text { (pró-credor) }\end{array}$ & $\begin{array}{c}\% \text { de ações } \\
\text { Aceitas } \\
\text { (pró-devedor) }\end{array}$ \\
\hline Menos de 3\% & 0 & 837 & $0,00 \%$ \\
$3-4 \%$ & 6 & 23 & $21,00 \%$ \\
$4-7 \%$ & 3 & 2 & $60,00 \%$ \\
Mais de 7\% & 17 & 0 & $100,00 \%$ \\
\hline
\end{tabular}

Não deixa de ser curioso termos conseguido obter tantas decisões mesmo após a aplicação de tantos filtros. A explicação mais plausível é a de que as cortes brasileiras sejam de fato bastante receptivas aos reclames de devedores em financiamentos de modo geral (se isso ocorre por simpatia a devedores, como se costuma acreditar, ou por antipatia à taxa de juros do contrato, como aqui sugerimos, é justamente o tema suscitado neste trabalho).

Os dados mais recentes divulgados pelo Conselho Nacional de Justiça (CNJ) apontam que as instituições financeiras eram, em 2011, as maiores litigantes privadas do Brasil, estando envolvidas em $12,95 \%$ de todos os novos processos judiciais na Justiça Estadual, e em 14,7\% de todos aqueles levados perante os Juizados Especiais Estaduais ${ }^{10}$ entre $1^{\circ}$ de janeiro de 2011 e 31 de outubro de $2011 .{ }^{11}$ Nos tribunais federais, a situação era apenas ligeiramente melhor, estando os bancos públicos envolvidos em 9,6\% de todas as ações judiciais iniciadas no período destacado. Embora os temas litigados sejam muito variados, englobando inclusive numerosas ações sobre tarifas e perdas inflacionárias, ${ }^{12}$ a questão mais comumente debatida tem sido a taxa de juros cobrada pelos bancos nas operações de crédito. Como se vê, há hoje no Brasil uma super-litigância envolvendo o crédito bancário (Salama, 2016).

Figura 1. Dispersão das taxas de juros (número de ações $\times$ taxa de juros).

(a) Das ações aceitas.

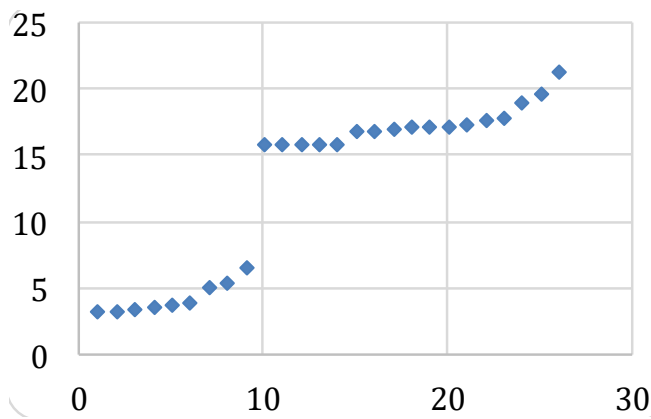

(b) Das ações rejeitadas.

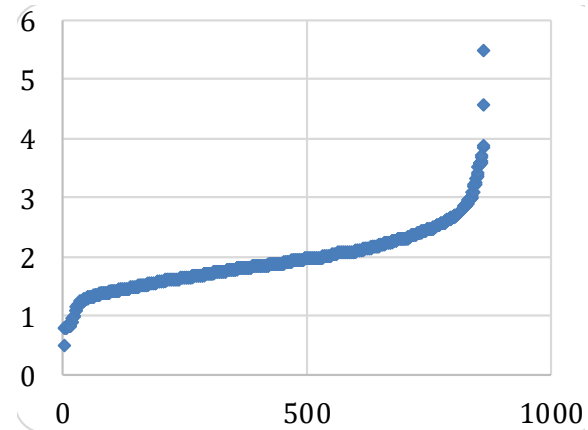

${ }^{10}$ Os juizados especiais no Brasil só podem julgar casos cujo valor envolvido seja igual ou inferior a quarenta salários mínimos.

${ }^{11}$ A pesquisa não inclui casos criminais, eleitorais e militares, bem como casos instaurados pelo Ministério Público (ver CNJ, 2012, pp.4-6).

${ }^{12} \mathrm{Em} 2014$, os contratos bancários em relações de consumo relativos a empréstimos consignados, expurgos inflacionários, planos econômicos e tarifas figuravam como o $20^{\circ}$ assunto mais demandado dentre todos os processos iniciados perante a Justiça Estadual naquele ano, e como $17^{\circ}$ dentre as demandas levadas aos Juizados Especiais Estaduais no mesmo período (CNJ, 2015, pp.98-100). 
Outro ponto a se notar é o de que há três "zonas" distintas nas decisões judicias: aquela em que as taxas de juros são sempre aceitas; aquela em que são sempre rejeitadas; e uma zona intermediária em que há decisões para os dois lados. Isso se explica, aparentemente, pela conjugação de dois fatores. De um lado, a jurisprudência entende de modo unívoco que juros "abusivos" podem ser revisados pelas cortes. De outro, prevalece no Poder Judiciário a orientação de que a abusividade somente pode ser aferida no caso concreto, e não com base em um critério geral.

Essa falta de clareza de critérios para além do parâmetro geral da "abusividade" fica clara quando se analisa as decisões do STJ, que é o tribunal responsável por unificar os entendimentos acerca da legislação infraconstitucional do país. Para ilustrar, no REsp 1.061.530/RS de 2010 - um celebrado leading case do STJ sobre revisão judicial da taxa de juros em contratos bancários — a Ministra relatora Nancy Andrighi indica que "a perquirição acerca da abusividade [da taxa de juros do contrato] não é estanque, o que impossibilita a adoção de critérios genéricos e universais."

É bem verdade que a Min. Nancy Andrighi procura encontrar elementos para a atuação do Judiciário. Em particular, "ataxa média de mercado, divulgada pelo Banco Central, constitui um valioso referencial [para a aferição da abusividade]". Assim, em seu voto são indicados precedentes em que o STJ considera abusivas taxas superiores a uma vez e meia (voto proferido pelo Min. Ari Pargendler no REsp 271.214/RS, Rel. p. Acórdão Min. Menezes Direito, DJ de 04.08.2003), ao dobro (REsp 1.036.818, Terceira Turma, Nancy Andrighi, DJe de 20.06.2008) ou ao triplo (REsp 971.853/RS, Quarta Turma, Min. Pádua Ribeiro, DJ de 24.09.2007) da "média de mercado". Ao mesmo tempo, insiste a Min. Andrighi, "cabe somente ao juiz, no exame das peculiaridades do caso concreto, avaliar se os juros contratados foram ou não abusivos". Não fica claro, no entanto, em que caso cada parâmetro (uma vez e meia, o dobro ou o triplo) deve ser usado.

É preciso notar, de qualquer forma, que a pesquisa realizada tratou de precedentes de juízes de primeira instância em São Paulo, mas nada garante que tais precedentes sigam fielmente os ditames do STJ, nem que em outros estados haja o mesmo padrão. Essa observação encontra fundamento, por exemplo, no trabalho de Yeung \& Azevedo (2015) que, analisando contratos comerciais de diversos tipos, chegaram ao surpreendente resultado de que $54,3 \%$ das decisões do STJ analisadas reformavam decisões dos tribunais estaduais. Este é, aliás, indício de que o problema de insegurança jurídica seja particularmente grave no Brasil, um tema que toca ao presente trabalho apenas de maneira indireta e que retomo na seção 5.2 abaixo.

Um ponto adicional é o de que para se chegar aos resultados desta pesquisa não foi necessário recorrer à análise pormenorizada da fundamentação jurídica empregada pelos magistrados (isto é, não precisamos catalogar as "razões de decidir" das sentenças). A ideia foi ater-se às preferências reveladas (nas decisões), e não às preferências declaradas (na fundamentação). 0 ponto é retomado em detalhe na seção 5.3, adiante.

Um comentário importante acerca da fundamentação das decisões pesquisadas, no entanto, é o de que não encontramos decisão em que o juiz tenha dito que não compete ao Poder Judiciário perquirir sobre a abusividade de taxas de juros. Mesmo os votos contrários ao tabelamento pelo Poder Judiciário da taxa de juros, ainda assim costumam conter a ressalva de que a abusividade deve ser analisada no caso concreto. Trata-se, a meu ver, de implicação da vedação ao abuso de direito, uma categoria dita "dogmática" (porque criada pela "doutrina") que permeia o pensar jurídico de modo, em parte, independente do texto das leis. ${ }^{13}$ Isso nos conduz de volta ao problema das mentalidades.

Por fim, cabe notar que aqui foi testada apenas a existência de correlação, e a inferência de causalidade requereria a realização de testes econométricos mais complexos. Por isso, não se pode descartar a possibilidade de que variáveis omitidas estejam determinando esses resultados (por exemplo, as ações

\footnotetext{
${ }^{13}$ Se bem que a vedação ao abuso de direito atualmente no Brasil decorre de lei. $C f$. art. 187 do Código Civil: "Também comete ato ilícito o titular de um direito que, ao exercê-lo, excede manifestamente os limites impostos pelo seu fim econômico ou social, pela boa-fé ou pelos bons costumes".
} 
rejeitadas podem se referir a devedores mais pobres ou com pior histórico de crédito, etc.). Tampouco se pode descartar a possibilidade de viés de seleção, porque aqui selecionamos apenas decisões em que o devedor era o autor da ação, e com isso deixamos de fora o universo de ações de cobrança ajuizadas pelos bancos contra os devedores. Ainda assim, tudo leva a crer que a razão principal para a aceitação de pedidos de redução/revisão contratual seja realmente a de que os juízes considerem as taxas de juros dos contratos analisados como "abusivas".

Em síntese, temos o seguinte. No Brasil, é comum os devedores contestarem a taxa de juros dos contratos. Este estudo enfocou os litígios envolvendo o financiamento de automóveis sob alienação fiduciária no estado de São Paulo. Os dados mostraram que a maioria dos pleitos judiciais visando à redução das taxas de juros é rejeitada, porém uma parcela não desprezível é aceita. Além disso, a proporção de casos aceitos aumenta conforme aumentam as taxas de juros do contrato em disputa. Esses resultados são consistentes com a hipótese orientadora deste trabalho, isto é, a de que conforme os juros aumentam há uma tendência à maior incidência de vitórias dos devedores.

\section{IMPLICAÇÕES NORMATIVAS}

\subsection{Para os estudos sobre spreads bancários}

Há duas formas de relacionar a hipótese de causalidade reversa aqui delineada com a literatura existente. Primeiro, a hipótese de viés anti-credor pode ser substituída pela hipótese de preferência por contratos com juros menores. Nessa linha, a probabilidade de decisões pró-devedor tenderia a crescer com o mark-up dos bancos na intermediação bancária. As hipóteses testáveis são as seguintes: quando aumentam as despesas administrativas dos bancos, a cunha fiscal, o lucro líquido dos bancos ou os recolhimentos compulsórios, os julgamentos em favor dos devedores se tornam mais frequentes.

Segundo, a hipótese de preferência por contratos com juros menores pode ser também um canal de transmissão das causas macroeconômicas do spread bancário. Assumindo, como é altamente plausível, que haja transmissão da rigidez monetária para o nível de spread, a hipótese testável é a de que a maior rigidez da política monetária cause aumento de decisões pró-devedor. Essa me parece uma hipótese particularmente interessante. A normalização financeira do Brasil após o Plano Real foi apenas parcial, porque embora os índices de inflação tenham caído, as taxas de juros permaneceram muito elevadas. Convém investigar a suspeita nada implausível de que esse desarranjo no nível macro tenha um reflexo, também, nos tribunais.

Um ponto adicional a ser enfatizado é que o levantamento empírico aqui realizado com financiamento de automóveis sob alienação fiduciária é replicável para outros tipos de financiamento. Contudo, nem sempre a pesquisa com outros tipos de financiamento bancário revelará a correlação aqui indicada, ainda que os juízes tenham de fato resistência a juros mais altos.

O motivo é o seguinte: o parâmetro mais comum para a identificação de abusividade é a discrepância ante a média das taxas de mercado. ${ }^{14}$ Uma questão enfrentada pelos bancos é que a média de mercado não captura variações que reflitam maior ou menor risco de crédito de diferentes devedores. Os bancos têm criado diferentes produtos para atender a clientes com perfis de risco distintos. Pode acontecer, então, que produtos financeiros com pequena variação na taxa de juros cobrada de diferentes tomadores não indiquem variações com significância estatística tal qual obtivemos no caso do financiamento de automóveis sob alienação fiduciária no estado de São Paulo.

\subsection{Para o debate sobre as políticas concorrenciais no setor bancário}

A hipótese de causalidade reversa objeto deste trabalho sugere que haja dois canais de transmissão entre a competição bancária e o nível de spread. O primeiro é bem conhecido: maior competição,

\footnotetext{
${ }^{14}$ Cf. seção 3.3 supra.
} 
menor mark-up pelos bancos. O segundo é sutil: menor mark-up, maior o nível de enforcement dos contratos pelo Judiciário e, então, novamente, menor spread bancário. $O$ estudo desse segundo canal de transmissão é importante para o debate existente no Brasil acerca do nível de competição desejado no sistema financeiro. Aqui há temas como inovação financeira (novos produtos, securitizações, etc.), barreiras de entrada (especialmente para as fintechs) e políticas pro-competitivas de modo geral (controle estrutural e de condutas, etc.).

\subsection{Para as iniciativas voltadas à expansão do crédito}

Da hipótese de causalidade reversa também decorre uma possível explicação para o racionamento de crédito no Brasil, porque o nível de enforcement estará progressivamente caindo sempre que a expansão do crédito se fizer (como é natural) em taxas de juros superiores àquelas anteriormente praticadas.

\subsection{Para a microeconomia teórica}

A literatura de microeconomia bancária reconhece que nem todo contrato será exigível perante o Poder Judiciário, porém a probabilidade de que o contrato não seja exigível tende a ser tratada como uma restrição exógena. A sugestão subjacente à hipótese aqui formulada é a de que a probabilidade de enforcement de um contrato possa ser endogeneizada como função do preço do contrato. Esse é, aliás, o caminho seguido em Guimarães \& Salama (2017).

\subsection{Para o debate sobre a imposição de tetos aos juros remuneratórios}

Se há uma preferência por juros mais baixos entre os membros do Poder Judiciário, como se sugere aqui, cabe pensar sobre os efeitos de uma lei estabelecendo um teto para a taxa de juros. Parece razoável supor que, se o teto for muito baixo, a tendência do Poder Judiciário será encontrar caminhos interpretativos que lhe permitam desconsiderar o teto (como ocorreu no Brasil quando em 1988 a Constituição Federal estabeleceu um teto de $12 \%$ de juros "reais" para operações financeiras). Por outro lado, se o teto for muitíssimo alto, ou se não houver teto (como de modo geral ocorre no caso brasileiro), corre-se também o risco de que a autorização legal seja ignorada e que o Judiciário passe a impor o seu próprio teto (e o que é pior, com grande variância, reduzindo a previsibilidade e aumentando a insegurança jurídica). Esse pode ser o caso brasileiro.

Guimarães \& Salama (2017) formulam a hipótese de que dentro de um certo intervalo os juízes seguem as leis, mas fora do intervalo os juízes adotam uma solução idiossincrática (ainda que pautada em algum critério de decisão, como, por exemplo, a "discrepância" ante a média de mercado). Fazendo suposições simples sobre as preferências dos juízes, pode-se chegar à conclusão de que um teto suficientemente alto pode reduzir a insegurança jurídica e permitir a expansão do mercado de crédito se puder angariar grande adesão dos membros do Poder Judiciário. A mensagem é: se houvesse um teto elevado, que fosse quase sempre seguido por todo o Poder Judiciário, então provavelmente o crédito poderia se expandir mais do que na situação atual em que, não havendo teto legislado, o Poder Judiciário intervém de forma desorganizada na precificação do crédito.

\subsection{Para as políticas públicas voltadas à redução do spread}

São duas. Primeiro, com ou sem a edição de uma nova lei da usura, o problema do spread alto não será resolvido se não se puder atacar também suas demais causas, especialmente (i) a elevada tributação do crédito, (ii) os problemas de competição (se existirem, o que não está cabalmente demonstrado) e, principalmente, (iii) o desarranjo macroeconômico do país que se transmite de maneira tão consequente para a elevação do piso das taxas de juros, para elevação da insegurança sobre a solvência do estado, para a redução da confiança pública de modo geral e para a elevação dos próprios spreads bancários. 
A criação dos mecanismos de dinamização da exigibilidade do crédito mencionados neste trabalho são evidentemente boas iniciativas, que convém ampliar. Mas as mudanças dos mecanismos judiciais são a parte mais fácil, e quem sabe até a parte menos importante do processo de normalização financeira do país.

Segundo, em linha com o modelo delineado em Guimarães \& Salama (2017), pode ser possível expandir a oferta de crédito introduzindo-se uma lei de usura. Para tanto, a lei teria que ter duas características importantes. Primeiro, teria que permitir taxas de juros suficientemente altas, para possibilitar a oferta de crédito a uma boa parcela dos devedores. Segundo, a lei teria que ser crível, no sentido de reduzir fortemente a imprevisibilidade/insegurança jurídica que advém da resistência de parcela dos juízes ainda contrários à precificação do juro em padrões elevados. ${ }^{15}$

\subsection{Para o debate público sobre o spread bancário}

A hipótese de causalidade reversa aqui delineada supõe que a preferência judicial seja pelo juro baixo; não pelo devedor. As implicações em cada caso são diferentes. Quando a preferência judicial é pelo devedor, há um grande espaço para o que em inglês se costuma chamar de advocacy, isso é, a defesa pública e sistemática de um certo conjunto de interesses (no caso, dos credores). O objetivo é reverter o viés.

Mas se a preferência for pelo juro baixo, a eficácia da advocacy pelos credores tende a ser menor. De nada adianta despontar no Judiciário certa simpatia pelos credores - reverter o que a literatura do viés anti-credor cogita serem preconceitos atávicos contra os Shylocks do mundo moderno - se o custo de crédito ainda é tido como muito alto. A predição da presente hipótese, portanto, é a da relativa ineficácia das tentativas dos credores de reverter o "viés anti-credor" pelo simples motivo de que tal viés provavelmente não existe.

É claro que as preferências dos juízes não são estáticas. 0 advocacy pode bem estender, digamos, 0 nível a partir do qual os juízes passam a achar os juros aceitáveis (se as opiniões de juízes não mudassem, talvez teríamos até hoje a resistência à cobrança de juros que tão claramente caracterizou todo o período da Idade Médida na Europa). Mas a melhor compreensão dos gostos (tastes) que motivam as preferências judiciais pode contribuir, no mínimo, para que o debate possa estar focado nos pontos verdadeiramente relevantes.

\section{LIÇÕES PARA O ECONOMISTA}

A hipótese aqui formulada tem uma singular característica: para o jurista, acostumado com as discussões em torno do problema do "abuso de direito", ela é intuitiva; mas para o economista, pouco acostumado a endogeneizar a probabilidade de enforcement ao preço do contrato, ela é contra-intuitiva. A sugestão é a de que há algo de importante sobre o sistema jurídico que escapa à interpretação dos economistas. Sem a pretensão de esgotar um assunto de todo espinhoso, esta seção se ocupa deste problema indicando quatro "lições" que podem ser tiradas em benefício do aprimoramento da análise econômica do direito e do Judiciário.

\subsection{Aplicar a lei não é um processo mecânico}

Em princípio, cabe ao juiz aplicar a lei aos fatos. Na teoria jurídica, esse processo recebe o nome de "subsunção". A lei contém o comando. As partes apresentam os fatos. 0 juiz apenas faz o encontro

\footnotetext{
${ }^{15}$ Além disso, dada a diferença de taxas de juros em diferentes produtos - compara-se o cheque especial com o crédito consignado - , essa lei de usura possivelmente teria que ser estabelecida "por produto", e não horizontalmente para todo tipo de financiamento.
} 
entre os fatos (que lhe são trazidos) e a lei (que é por ele conhecida). Juízes são como máquinas de ler leis e contratos. $O$ processo de decisão é automático.

Acontece que esse modelo de subsunção não descreve adequadamente o ato de julgar. Decidir litígios não é um ato mecânico. Ao contrário, julgar envolve o exercício da razão prática, do juízo, da deliberação sobre os fatos, o contrato e as leis. Repare: contratos com juros contratuais elevados podem ser tidos como ilegais pelo Poder Judiciário ainda que a cobrança de preço de mercado esteja em princípio permitida pela legislação, como, aliás, ocorre no Brasil. A legislação específica permite; o juiz proíbe. Que o juiz o faça com base em leis gerais, em doutrinas de antanho ou em princípios constitucionais em nada muda o problema econômico. É isso que torna plausível a hipótese aqui delineada.

Vamos reiterar o ponto. Se a subsunção mecânica explicasse o processo de decisão dos juízes, então as decisões do Poder Judiciário sobre os contratos de financiamento dependeriam apenas dos comandos contidos na legislação. E o que estabelece a legislação brasileira sobre a taxa de juros? De modo geral, ela permite que o contrato de financiamento seja precificado com base nas condições de mercado porque, como vimos, os tetos à cobrança de juros previstos na legislação brasileira - particularmente no Decreto 22626/33 (a chamada "Lei da Usura") e no Código Civil de 2002 - foram, em 1964, excepcionados para as instituições financeiras. Estabeleceu-se, assim, um sistema dual, em que apenas as instituições financeiras podem cobrar juros de mercado, enquanto que os demais agentes econômicos devem seguir os tetos estabelecidos na legislação.

Ora, se a legislação dispõe dessa forma, então o modelo simplificado de subsunção acima delineado levaria à conclusão de que a taxa de juros não deveria influenciar o enforcement do contrato. Preenchidos os requisitos de validade básicos (capacidade para assinar o contrato, especificação do valor emprestado e da taxa de juros, ausência de erro ou fraude, etc.) caberia ao Poder Judiciário apenas mandar cumprir — dar o enforcement - os contratos e as garantias do financiamento. Mas a hipótese deste trabalho é que o Poder Judiciário esteja mais propenso a invalidar contratos - julgar a favor de devedores - à medida que a taxa de juros do financiamento aumente.

É por isso que dissemos que o modelo de subsunção — poderíamos chamá-lo também de modelo "formalista" - não descreve bem como o direito funciona. Muitos teóricos do direito, e talvez mesmo economistas, poderiam inclusive entender que o sistema jurídico deveria funcionar desse modo. Esse é um bom debate normativo (os juristas o chamariam de "deontológico"). Sem enfrentar a complexidade toda do problema, pode-se aqui pontuar que a ideia de uma subsunção mecânica traz muitas dificuldades práticas. A legislação pode padecer de uma série de problemas: pode ter se tornado antiquada; pode ser contraproducente; pode ser obscura; pode ser contraditória; pode ser discriminatória; e assim por diante. Tudo isso sugere cautela com visões radicais da ideia de subsunção.

É claro que o debate não acaba aqui. Da mesma forma que o Judiciário pode corrigir uma má legislação ele pode, também, arruinar uma boa legislação. Imaginemos novamente que o juiz realize um teste de hipótese com uma regra legislada. ${ }^{16}$ Se a hipótese nula for "a regra deve ser seguida" e a hipótese alternativa for "a regra deve ser ignorada", pode haver dois erros: o erro tipo 1, em que a regra é ignorada quando deveria ser seguida; ou o erro tipo 2, em que o juiz segue a regra legislada quando deveria ignorá-la. O problema da vinculação do juiz à legislação, como se vê, se presta a muitas sutilezas.

\subsection{A relativa imprevisibilidade é inerente ao sistema jurídico}

Até aqui falamos da decisão judicial sobre a substância das regras em vigor, mas há evidentemente um outro problema ligado à atuação, digamos, criativa, do Poder Judiciário, que diz respeito à previsibilidade das regras. Se por um lado o legislador erra, por outro o Judiciário pode errar também; mas talvez seja melhor conviver com uma má regra que seja conhecida e estável - até para que barganhas coaseanas sejam possíveis - do que com um regramento instável ou desconhecido. Tudo isso mostra que o

${ }^{16}$ Cf. seção 1 , supra. 
debate normativo sobre o formalismo jurídico (inclusive seus desdobramentos econômicos) é muito rico, complexo e, como quase tudo em matéria de teoria jurídica, vem de longa data e nunca foi resolvido.

A hipótese de causalidade reversa não lança novas luzes sobre essa discussão milenar, mas aponta para dois fatos que geralmente não costumam ser bem compreendidos nos estudos de análise econômica do direito. Primeiro, a situação normal de um sistema jurídico é aquela em que o Poder Judiciário geralmente segue a legislação, mas excepcionalmente atua de maneira criativa. 0 juiz atua, então, como um "legislador ocasional", para tomarmos emprestada a expressão de Richard Posner (2008, p.78).

Segundo, a situação normal do sistema jurídico é haver certa insegurança jurídica, isto é, certa imprevisibilidade. A insegurança jurídica pode ser pensada como uma variância em torno de um ponto médio das decisões. Ela não decorre apenas da atuação criativa do Judiciário, mas esta é um fator impulsionador. Na política, há sempre um elemento de surpresa — o que fará o legislador? — mas é normal haver também esse tipo de incerteza no que toca à atuação do Judiciário. Isso não quer dizer, evidentemente, que a existência dessa incerteza seja boa; quer dizer apenas que ela seja um dado da realidade.

Há aqui uma decorrência muito importante: a circunstância de estar um sistema judicial funcionando bem, ou mal, é uma questão de grau. Um sistema judicial disfuncional erra muito e é pouco previsível (tem elevada variância entre as decisões); um bom sistema jurídico erra pouco e é muito previsível (tem baixa variância); e entre essas duas situações polares há diversos casos de meio-termo. Onde o Brasil está, nesse contínuo, é também uma boa questão, sobre a qual existe literatura, e da qual não me ocupei aqui.

De qualquer forma, a formulação nesses termos indica ser possível pensar-se em uma otimização da atuação criativa do Poder Judiciário como um trade-off entre eliminação de erros do legislador e preservação da segurança jurídica. E aqui não vai nenhuma sugestão de que o Poder Judiciário necessariamente "acerte" mais do que o legislador, embora haja uma longa tradição na economia de pensar-se desse modo (Hayek, 1960, 1973; Posner, 1977).

\subsection{Ninguém sabe ao certo o que os juízes maximizam}

As tentativas até hoje existentes de modelar uma curva de utilidade judicial são interessantes, mas têm se mostrado inconclusivas (Kornhauser, 2008, revisando a literatura). É curioso notar como a análise econômica acaba, então, por prescindir de micro-fundamentação das decisões dos juízes com base em uma curva de utilidade. Políticos maximizam votos, consumidores maximizam bem-estar, burocratas maximizam poder, assim vai a teoria da escolha pública. E os juízes, o que maximizam? Não há boa resposta (Posner, 1993; Posner, 2008, p.36).

A fim de contornar o problema, é intuitivo pensar-se em mecanismos de revelação de preferências. A literatura econômica brasileira o faz profusamente, especialmente através da aplicação de questionários como aqueles mencionados na seção 2 acima. Esses questionários são, no fundo, de mecanismos de identificação de preferências declaradas, estando sujeitos, portanto, aos conhecidos problemas ligados a essa técnica (ambiguidades na formulação de perguntas e respostas, desonestidade na resposta, inconsciência dos indivíduos sobre suas reais motivações).

Um outro caminho possível seria a inferência de preferências a partir dos fundamentos jurídicos das decisões judiciais. Afinal, ao decidir, determina a Constituição Federal (art. 93, IX), o juiz deve fundamentar, isto é, indicar as razões jurídicas de decidir. No sistema de direito continental que vigora no Brasil, isso geralmente se traduz na indicação de algum artigo de lei que alegadamente embasa, ou "controla", a decisão, ao lado de uma argumentação sobre a pertinência entre tal artigo de lei e os fatos em questão (no sistema da Common Law a indicação de um precedente judicial pode bastar). Nesse embasamento legal reside o que estou chamando de fundamento jurídico.

Teoricamente, a indicação do fundamento jurídico poderia revelar a preferência do juiz. Daí teríamos, então, uma boa pista para compreender seus gostos, sua motivação, e quem sabe até para esboçar 
sua curva de utilidade. Acontece que nada garante que os juízes usarão fundamentos jurídicos verdadeiros para exprimir a motivação de suas decisões. Pode bem acontecer que um juiz opte por indicar um fundamento jurídico de decidir apenas por ser este o fundamento menos controverso, ou o mais popular, ou o mais politicamente correto, ou o mais dificilmente reversível. Isso quer dizer que a fundamentação jurídica padece dos mesmos problemas que se costuma atribuir aos questionários de declaração de preferências.

Há muitos textos eruditos destrinchando o problema do intervalo que separa motivação formal (declarada) e a motivação subjetiva (psicológica) das decisões judiciais, mas um depoimento aparentemente cândido do Ministro do STF, Luiz Fux, talvez o ilustre de forma emblemática. Confira-se: "Como magistrado, primeiro procuro ver qual é a solução justa. E depois, procuro uma roupagem jurídica para essa solução. Não há mais possibilidade de ser operador de Direito aplicando a lei pura. Nós aprendemos assim por força de um engessamento levado pela política de repressão, e que hoje não existe mais". ${ }^{17}$ Sendo assim, a fundamentação talvez ainda sirva para circunscrever os contornos do debate em juízo, algo que interessa apenas aos advogados. Mas para o economista, o resultado é a pouca importância da fundamentação como mecanismo de revelação de preferência.

\subsection{Nem toda lei contém uma regra}

Um problema adicional é que os fundamentos jurídicos para invalidação de contratos que preenchem requisitos mínimos de validade (como partes capazes, objeto lícito, forma prescrita em lei, etc.) não estão apenas em intuições de justiça, doutrinas e outros preceitos, mas estão também nas próprias leis escritas. Dito de forma simples: a própria legislação contém comandos que realçam a legitimidade do juiz para agir com discricionariedade, inclusive invalidando acordos voluntários. A literatura econômica (Ehrlich \& Posner, 1974; Kaplow, 1992) trata do problema a partir da distinção entre regras (comandos mais especificados) e standards (menos). Para ilustrar: a autorização à cobrança de juros remuneratórios em condições de mercado é uma regra. A vedação à cobrança em padrões "abusivos" é um standard.

$O$ ponto é que, para além de regras regulatórias mínimas (o contrato não pode ser assinado por um menor, o contrato deve ser datado, etc.), a legislação contém um enorme conjunto de normas abertas que outorgam ao juiz uma liberdade decisória e um espaço de discricionariedade maior. Os melhores exemplos são as chamadas cláusulas gerais (como a boa-fé e a função social) e os chamados conceitos jurídicos indeterminados - como estado de necessidade, preço justo e o próprio abuso de direito) (Salama \& Silva Filho, 2013). Há ainda princípios constitucionais, que contemplam aspirações de justiça e em alguns casos são utilizados como fundamento para decisão. O resultado é o seguinte: um juiz que discorde da legalidade de um contrato com uma taxa de juros muito elevada tem a seu dispor um verdadeiro arsenal conceitual de que pode se valer a fim de invalidar o contrato.

É bom também esclarecer que a fundamentação jurídica em normas abertas para invalidar contratos não é um fenômeno apenas brasileiro. Apenas para ficarmos no campo da discussão dos juros em contratos de financiamento, pode-se citar o caso da Suprema Corte alemã, que entendeu que juros em contratos de financiamento que excedam o dobro da média do mercado são contrários à moral pública, estando, portanto, em desacordo com o disposto no art. 138 do Código Civil alemão (Markesinis, Unberath \& Johnston, 2006; Reifner \& Schröder, 2012). ${ }^{18}$

A Suprema Corte japonesa, da mesma forma, recentemente mudou interpretação sobre a legislação aplicável aos financiamentos aos consumidores, e o efeito prático foi o de permitir uma avalanche de ações por parte de consumidores presos a contratos tidos por muito onerosos (Ramseyer, 2013). Isso

\footnotetext{
${ }^{17}$ Luiz Fux, depoimento disponível no website da Faculdade de Direito da UERJ (Universidade Estadual do Rio de Janeiro): http: // www.direitouerj .org.br/2005/fdir70/depLF.htm (acessado em: 15/11/2016).

${ }^{18}$ Essa decisão da Suprema Corte alemã tem pelo menos duas manifestações parecidas no STJ. Cf. REsp 977.789/RS, Terceira Turma, DJe de 20.06.2008; e REsp 1.036.818, Terceira Turma, DJe de 20.06.2008.
} 
quer dizer que os dilemas ligados à intervenção do Poder Judiciário na contratação privada se fazem sentir também fora do Brasil. Se em maior ou menor grau, este é um problema que requer um estudo que está além dos presentes fins.

De qualquer forma, ao falar da intervenção judicial nos contratos não quero dizer que cada juiz seja um pequeno déspota, alguém que não se prenda a nada e simplesmente resolva como quer. A aplicação do direito não deveria ser um vale tudo, assim dizem os teóricos do direito. E a prática judiciária do direito no Brasil não é um vale-tudo, assim digo eu. E por que esta prática não é um vale-tudo? Primeiro porque os juízes passam pela faculdade de direito, um local em que são doutrinados na proposição de que sua legitimidade política se prende mais ao ato de cumprir as regras do que ao ato de criá-las.

Segundo, e mais importante, porque essas crenças são reforçadas pela estrutura de incentivos criada pelo funcionamento do Poder Judiciário. Como já apontado pela literatura (Landes \& Posner, 1975), toda a estruturação do Poder Judiciário busca insular os juízes do resultado de suas decisões. Juízes não podem julgar causas em que tenham interesse direto e não recebem remuneração adicional pelo tipo de decisão; não tendo nada a ganhar criando regras, supõe-se, optarão por aplicar aquelas já existentes.

Mas da rejeição à ideia de que a aplicação do direito seja um vale-tudo não segue a afirmação do seu oposto, isto é, não segue que a aplicação do direito seja mecânica e que os juízes sejam autômatos. Embora na faculdade os juízes sejam, como dissemos, doutrinados na proposição de que sua legitimidade esteja ligada principalmente à aplicação de regras já legisladas, também nas faculdades recebem instrução no sentido de que devam aplicar o direito com prudência, atentar para os valores morais subjacentes às leis, exercer a razão prática e, em alguns casos, até mesmo julgar contra legem - contra o texto de lei. Além disso, a insulação dos juízes frente aos resultados dos litígios é apenas parcial, porque seus vieses e ideologias impactam suas decisões (Epstein, Landes \& Posner, 2013). É nesse ponto, aliás, que a discussão sobre a existência de viés anti-credor no Brasil encontra a literatura internacional.

Ademais, embora os juízes não possam julgar casos com os quais estejam diretamente envolvidos — por exemplo, um juiz não pode julgar uma ação se o seu filho for um dos advogados da causa — os juízes ainda julgarão casos com os quais estarão indiretamente envolvidos. E no caso dos financiamentos bancários, a consequência prática é facilmente compreendida. Basta pensar que todo juiz pode ser, pode ter sido, ou pode aspirar a ser titular de um financiamento bancário. Esse fato pode influenciar sua decisão.

Tudo isso quer dizer, então, que há fundamentos jurídicos que permitem aos integrantes do Poder Judiciário deliberarem sobre a conveniência de dar enforcement a um contrato. 0 preço do contrato, ou seja, a taxa de juros em um financiamento, é um dos componentes sobre os quais os juízes podem deliberar. Isso é importante porque o recurso a esses tipos de fundamentos mais abertos pode servir para afastar a exigibilidade de um contrato de financiamento consensualmente pactuado.

\subsection{O Direito pode excepcionar o critério de Pareto}

Causará estranheza ao economista a ideia de que contratos prévia e voluntariamente acordados possam ser revisados pelo Poder Judiciário. A teoria econômica dos contratos, nos lembra a conhecida sistematização de Cooter \& Ulen (2004, p.8), dirá que a eficiência econômica exige que se faça cumprir uma promessa se tanto o promitente quanto o promissário quiserem sua exigibilidade quando ela foi feita. Quando um acordo pode ser descumprido ex post, limita-se coordenação privada ex ante, reduz-se a fronteira de possiblidades de produção, cria-se um peso morto, e assim por diante. Tudo isso, aliás, deveria ser perfeitamente intuitivo, e pode ser demonstrado com a teoria dos jogos mais elementar.

Chegamos então à maior dificuldade do pensar em Direito e Economia: os critérios normativos da Economia e do Direito podem não coincidir. O critério normativo da economia é o custo e seu horizonte, portanto, é o da eficiência; o direito, por outro lado, ocupa-se de distinguir o legal do ilegal, mas o faz com base em critérios normativos bastante diversos (Katz, 2006; Salama, 2008). É bem verdade que há superposições entre as lentes de análise: há algo de injusto no desperdício, e o desperdício não é senão a 
ausência de eficiência. Por isso, muito do que é ineficiente é, também, tratado juridicamente como ilegal. Só que nem sempre é desse modo, porque em alguns casos o direito pode permitir o desperdício - a ineficiência - em nome da defesa de algum outro valor.

A implicação aqui é clara: é no mínimo ingênuo acreditar que um Judiciário independente, em qualquer lugar do mundo, possa estar comprometido com a força obrigatória dos contratos (e o princípio de Pareto) em absolutamente todos os casos. Contratos de escravidão, de prestação de serviços sexuais, as loterias de órgãos, dentre muitos outros, serão ilegais ainda que realizados voluntariamente, por partes capazes, perfeitamente informadas e sem gerar consequências negativas para terceiros. No fundo, o que está por trás da hipótese de causalidade reversa aqui formulada é que contratos com juros muito elevados talvez caiam também nessa circunstância de ilegalidade mesmo quando a precificação for justificável do ponto de vista da relação risco-retorno do negócio.

\section{CONCLUSÃO}

O sistema jurídico faz parte do conjunto de mecanismos institucionais que implementam as políticas de crédito. Este sistema jurídico está baseado em critérios que englobam, mas não se limitam, ao princípio de eficiência Paretiana. Isso quer dizer que nem sempre o que é combinado voluntariamente será exigível judicialmente. À luz da literatura existente e do levantamento empírico realizado, é plausível supor que o Poder Judiciário esteja tanto mais propenso a rejeitar a taxa de juros pactuada nos contratos quanto mais elevado for o nível dessa taxa de juros.

\section{REFERÊNCIAS BIBLIOGRÁFICAS}

Afanasieff, T. S., Lhacer, P. M. V. \& Nakane, M. (2002). The determinants of bank interest spread in Brazil (Working Paper Series $\mathrm{N}^{0}$ 46). Banco Central do Brasil.

Aith, M. (1998). The judiciary's impact on the activities of financial institutions. In A. C. Pinheiro (Ed.), Economic costs of judicial inefficiency in Brazil. São Paulo: Idesp.

Alencar, L., Andrade, R. \& Barbosa, K. (2017). Bank competition and the limits of creditor's protection reforms. Disponivel em: https://kleniobarbosa.files.wordpress.com/2017/03/bankcompbbr.pdf

Alencar, L. S. (2011, March). Revisiting bank pricing policies in Brazil: Evidence from loan and deposit markets (Working Paper Series $\mathrm{N}^{0}$ 235). Brasília, DF: Banco Central do Brasil. Disponível em: https://www.bcb.gov.br/ pec/wps/ingl/wps235.pdf

Amadeo, E., \& Camargo, J. M. (1996). Instituições e o mercado de trabalho no Brasil. In J. M. Camargo (Ed.), Flexibilidade do mercado de trabalho no Brasil. Rio de Janeiro: Editora FGV.

Araujo, A.P. d., Ferreira, R.d. V.X. \& Funchal, B. (2012). The Brazilian bankruptcy law experience. Journal of Corporate Finance.

Arida, P., Bacha, E. L. \& Resende, A. L. (2005). Credit, interest, and jurisdictional uncertainty: Conjectures on the case of Brazil. In F. Giavazzi, I. Goldfajn \& S. Herrera (Eds.), Inflation targeting, debt, and the Brazilian experience, 1999 to 2003. Cambridge: MIT Press.

Aronovich, S. (1994). Uma nota sobre os efeitos da inflação e do nível de atividade sobre o spread bancário. Revista Brasileira de Economia, 48(1).

Banco Mundial. (2006). Brazil interest rates and intermediation spreads. Banco Mundial.

Banco Mundial. (2015). Interest rate spread, 2015. Banco Mundial. Acessado em 15/11/2016: http://data.worldbank . org/indicator/FR.INR.LNDP?end $=2015 \&$ start $=1988 \& v i e w=$ chart\&year_high_desc $=$ true

Barbosa, K., Cardoso, M. \& Azevedo, P. (2016). Concorrência no setor bancário brasileiro: Bancos individuais versus conglomerados bancários. Pesquisa e Planejamento Econômico, 46(1). 
Barbosa, K., Rocha, B. d.P. \& Salazar, F. (2015). Assessing competition in the banking industry: A multi-product approach. Journal of Banking \& Finance, 50.

Barboza, R. d. M. (2015). Taxa de juros e mecanismos de transmissão da política monetária no Brasil. Revista de Economia Política, 35(1).

BCB. (1999). Juros e spread bancário no Brasil. Banco Central do Brasil.

BCB. (2000). Juros e spread bancário no Brasil: Avaliação de 1 ano do projeto. Banco Central do Brasil.

BCB. (2001). Juros e spread bancário no Brasil: Avaliação de 2 anos do projeto. Banco Central do Brasil.

BCB. (2002). Juros e spread bancário no Brasil: Avaliação de 3 anos do projeto. Banco Central do Brasil.

BCB. (2003). Juros e spread bancário no Brasil: Avaliação de 4 anos do projeto. Banco Central do Brasil.

BCB. (2004a). Juros e spread bancário no Brasil: Avaliação de 5 anos do projeto. Banco Central do Brasil.

BCB. (2004b). Relatório de economia bancária e crédito 2004. Banco Central do Brasil.

BCB. (2005). Relatório de economia bancária e crédito 2005. Banco Central do Brasil.

BCB. (2014). Relatório de economia bancária e crédito 2014. Banco Central do Brasil.

Belaisch, A. (2003). Do Brazilian banks compete? (IMF Working Paper $\mathrm{N}^{0}$ 03/113). International Monetary Fund. Disponivel em: https://www.imf.org/external/pubs/ft/wp/2003/wp03113.pdf

CNJ - Conselho Nacional de Justiça. (2012). 100 maiores litigantes 2011. Conselho Nacional de Justiça. Acessado em 15/11/2016: http://www.cnj.jus.br/images/pesquisas-judiciarias/Publicacoes/100_maiores_litigantes.pdf

CNJ - Conselho Nacional de Justiça. (2015). Justiça em números 2015. Conselho Nacional de Justiça.

Cooter, R., \& Ulen, T. (2004). Law and economics (2 $₫$ ed.). Boston: Pearson Addison-Wesley.

Ehrlich, I., \& Posner, R. A. (1974). An economic analysis of legal rulemaking. The Journal of Legal Studies, 3(1).

Epstein, L., Landes, W. M. \& Posner, R. A. (2013). A theoretical and empirical study of rational choice. Massachusetts: Harvard University Press.

Ferrão, B. L. d. M., \& Ribeiro, I. C. (2007). Os juízes brasileiros favorecem a parte mais fraca? In E. C. Teixeira \& M. J. Braga (Eds.), Instituições e desenvolvimento econômico. Viçosa: Editora UFV.

FMI - Fundo Monetário Internacional. (2012). Brazil: Financial system stability assessment. Disponível em: https://www.imf.org/external/pubs/ft/scr/2012/cr12206.pdf

Gelos, G. (2006). Banking spreads in Latin America (Working Paper No 06/44). IMF.

Guimarães, B., \& Salama, B. M. (2017). Contingent judicial deference: Theory and application to usury laws.

Hayek, F. A. v. (1960). The constitution of liberty. Chicago: University of Chicago Press.

Hayek, F. A. v. (1973). Law, legislation and liberty: A new statement of the liberal principles of justice and political economy. London: Routledge.

Kaplow, L. (1992). Rules versus standards: An economic analysis. Duke Law Journal, 42.

Katz, L. (2006). Choice, consent, and cycling: The hidden limitations of consent (Relatório técnico $\left.\mathrm{N}^{0} 111\right)$. University of Pennsylvania Law School Faculty Scholarship Paper.

Kornhauser, L. (2008). The analysis of courts in the economic analysis of law. In G. Caldeira, D. Kelemen \& K. Whittington (Eds.), The oxford handbook of law and politics. Oxford: Oxford University Press.

Koyama, S. M., Annibal, C. A., Bader, Cymrot, F. L., Lundberg, E. \& Takeda, T. (2008). Decomposição do spread bancário e apresentação de nova metodologia. In Banco Central do Brasil (Ed.), Relatório de economia bancária e crédito. Banco Central do Brasil.

Laeven, G., L. e Majoni. (2003). Does judicial efficiency lower the cost of credit? (World Bank Policy Research Working Paper $\mathrm{N}^{0}$ 3159). Banco Mundial. 
Lamounier, B., \& De Sousa, A. (2002). As elites brasileiras e o desenvolvimento nacional: Fatores de consenso e dissenso. São Paulo: Idesp.

Landes, W. M., \& Posner, R. A. (1975). The independent judiciary in an interest-group perspective. Journal of Law and Economics, 18(3).

La Porta, R., Lopez-De-Silanes, F., Shleifer, A. \& Vishny, R. (1998). Law and finance. The Journal of Political Economy, 106(6).

Lucinda, C. R. (2010). Competition in the Brazilian loan market: An empirical analysis. Estudos Econômicos, 40(4), 831-858. doi: 10.1590/S0101-41612010000400004

Manhiça, F. A., \& Jorge, C. T. (2012). O nível da taxa básica de juros e o spread bancário no Brasil: Uma análise de dados em painel (Texto para discussão $\mathrm{N}^{0}$ 1710). Ipea.

Markesinis, B. S., Unberath, H. \& Johnston, A. (2006). The German law of contract: A comparative treatise. Bloomsbury Publishing.

Milhaupt, C., \& Pistor, K. (2008). Law and capitalism. The University of Chicago Press.

Nakane, M. I., \& Rocha, B. (2010). Concentração, concorrência e rentabilidade no setor bancário brasileiro: Uma visão atualizada. Tendências Consultoria Integrada - Febraban.

North, D. C. (1991). Institutions. The Journal of Economic Perspectives, 5(1).

Nunes, M. G., \& Trecenti, J.A.Z. (2015). Reformas de decisão nas câmaras de direito criminal em São Paulo. Acessado em 15/11/2016: http://s.conjur.com.br/dl/estudo-camaras-criminais-tj-sp.pdf

Oliveira, G. C. d., \& Carvalho, C.E. (2007). O componente "custo de oportunidade" do spread bancário no Brasil: Uma abordagem pós-keynesiana. Economia e Sociedade, 16(3).

Ono, F. H., Oreiro, J. L., Paula, L. F. d. \& Silva, G. J. C. d. (2004). Spread bancário no Brasil: Determinantes e proposições de política. In J. Sicsú, L. F. d. Paulo \& R. Michel (Eds.), Novo desenvolvimentismo: Um projeto nacional de crescimento com equidade social. Barueri: Manole.

Paula, L. F. d., \& Oreiro, J. L. (Eds.). (2007). Sistema financeiro: Uma análise do setor bancário brasileiro. Rio de Janeiro: Elsevier.

Pinheiro, A. C. (1996). Judicial system performance and economic development. In Economic growth, institutional quality and the role of judicial institutions. Washington, D.C.: University of Maryland.

Pinheiro, A. C. (Ed.). (1998). Economic costs of judicial inefficiency in Brazil. São Paulo: Idesp.

Pinheiro, A. C. (2003). Direito e economia num mundo globalizado: Cooperação ou confronto? (Texto para discussão $\mathrm{N}^{0}$ 963). Ipea.

Pinheiro, A. C., \& Cabral, C. (1998). Credit markets and institutions in Brazil. Ensaios BNDES(9).

Pinheiro, A. C., \& Cabral, C. (2001). Credit markets in Brazil: The role of the judiciary and other institutions. In M. Pagano (Ed.), Defusing default: Incentives and institutions. Washington: Inter-American Development Bank.

Ponticelli, J., \& Alencar, L. (2013). Celeridade do sistema judiciário e crédito bancários para as indústrias de transformação (Working Paper $\mathrm{N}^{0}$ 327). Banco Central do Brasil.

Posner, R. A. (1977). Economic analysis of law (2 $\underline{\underline{a}}$ ed.). Aspen Publishers.

Posner, R. A. (1993). What do judges and justices maximize? (The same things everyone else does) (Working Paper $\mathrm{N}^{0}$ 15). Coase-Sandor Institute for Law \& Economics.

Posner, R. A. (2008). How judges think. Massachusetts: Harvard University Press.

Priest, G., \& Klein, B. (1984). The selection of disputes for litigation. Journal of Legal Studies, 13. 
Ramseyer,J. M. (2013). Bottom-feeding at the bar: Usury law and value-dissipating attorneys in Japan (Discussion Paper $\mathrm{N}^{0} 741$ ). Harvard Law School.

Reifner, U., \& Schröder, M. (Eds.). (2012). Usury laws: A legal and economic evaluation of interest rate restrictions in the european nion. Norderstedt: BoD-Books.

Ribeiro, I. C. (2007). Robin Hood versus King John: Como os juízes locais decidem casos no Brasil [Prêmio IPEACAIXA 2006 - Monografias Premiadas]. Ipea.

Sadek, M. T. (1995). A crise do judiciário vista pelos juízes: Resultados da pesquisa quantitativa. In M. T. Sadek (Ed.), Uma introdução ao estudo da justiça. Editora Sumaré.

Salama, B. M. (2008). O que é pesquisa em Direito e Economia. Cadernos Direito GV, 5(2).

Salama, B. M. (2012). Vetores da jurisprudência na interpretação dos contratos bancários no Brasil. Revista de Direito Bancário e do Mercado de Capitais, 57.

Salama, B. M. (2016). Crédito bancário e judiciário: Condutores institucionais da superlitigância. In M. M. Prado (Ed.), O judiciário e o estado regulador brasileiro. São Paulo: FGV Direito SP.

Salama, B. M., \& Silva Filho, O. d. (2013). Elasticity, incompleteness, and constitutive rules. Columbia Law School Blog Blue Sky.

Vianna, L. W., Carvalho, M. A. R., Melo, M. P. C. \& Burgos, M. B. (1996). O perfil do magistrado brasileiro [Projeto Diagnóstico da Justiça].

Yeung, L., \& Azevedo, P. F. d. (2015). Nem Robin Hood, nem King John: Testando o viés anti-credor e anti-devedor dos magistrados brasileiros. Economic Analysis of Law Review, 6(1).

Yeung, L., Carvalho, C. E. \& Silva, A. L. (2012). A insegurança jurídica também é do devedor: Seleção adversa e custo do crédito no Brasil. Direito e Economia 30 anos de Brasil, 2. 